\title{
Probability of Hypertension in Advancing Ages of Women
}

\author{
Fajar Awalia Yulianto, ${ }^{1}$ Nurul Romadhona, ${ }^{1}$ Febyana Rosarianto, ${ }^{2}$ Vihannis Rahmanda, ${ }^{3}$ \\ Salman Barlian, ${ }^{3}$ Tresya Anggi Tania, ${ }^{3}$ Romy Reynaldi Gunawan, ${ }^{3}$ Sumayya Nuri \\ Fuadana Aulia Ul Haque, ${ }^{3}$ Rifa Nataputri, 3 Aulia Nur Amalia, 3 Paulina Maresta, 3 \\ Haris Nugroho ${ }^{3}$ \\ ${ }^{1}$ Department of Public Health, Faculty of Medicine, Universitas Islam Bandung, Bandung, Indonesia, \\ ${ }^{2}$ UPTD Pelayanan Kesehatan Kecamatan Pasirjambu, Bandung, Indonesia, \\ ${ }^{3}$ Medical Undergraduate Study Program, Faculty of Medicine, Universitas Islam Bandung, Bandung, Indonesia
}

\begin{abstract}
Hypertension is a problem in Indonesia, with 34.1\% prevalence. The number reflected the number of hypertensive patients in the 2016 clinic report of Pasirjambu Public Health Center as the most prominent non-communicable disease. This research aimed to discover the specific age of onset and risk factors of hypertension in the village where the health center located. A rapid survey collected the data in May 2017, where 210 women (representing their household) were chosen by randomization inside their respective clusters. Risk factors were analyzed by a robust and parsimonious logistic regression model along with probability count on age as the final prediction. The prevalence of hypertension was 59.5\% $(95 \% \mathrm{CI}=52.9,66.2 \%)$. Risk factors for hypertension were age $(\mathrm{OR}=1.06, \mathrm{p}=0.00)$, stress $(\mathrm{OR}=1.74, \mathrm{p}=0.09)$ and family history $(\mathrm{OR}=1.99, \mathrm{p}=0.03)$ but the protective factor was consumption frequency of salty food $(\mathrm{OR}=0.64, \mathrm{p}=0.10)$. In conclusion, a woman would have a $42.9 \%$ chance $(95 \% \mathrm{CI}=33.7,52.1 \%)$ for having hypertension at 40 years old of age after adjusted by other risk factors. Despite only two modifiable risk factors that can be intervened with, it would be worth trying to decrease the pace of onset in hypertension and the prevalence.
\end{abstract}

Key words: Age, hypertension, probability, risk factors, women

\section{Kemungkinan Hipertensi berdasar atas Usia pada Wanita}

\begin{abstract}
Abstrak
Hipertensi merupakan sebuah masalah di Indonesia dengan prevalensi sebesar 34,1\%, angka tersebut terlihat dalam laporan tahunan Puskesmas Pasirjambu sebagai penyakit tidak menular terbanyak di wilayah kerjanya. Tujuan penelitian ini adalah mengetahui usia munculnya hipertensi dan faktor risikonya. Pengumpulan data dilakukan melalui survei cepat di bulan Mei 2017, melibatkan 210 wanita yang mewakili rumah tangganya dipilih secara random. Faktor risiko dianalisis menggunakan regresi logistik dengan hasil akhir berupa prediksi kemungkinan. Hasil penelitian menunjukkan prevalensi hipertensi sebesar 59,5\% (IK95\%=52,9; 66,2\%). Usia (OR=1,06; $\mathrm{p}=0,00)$, stres $(\mathrm{OR}=1,74 ; \mathrm{p}=0,09)$ dan riwayat hipertensi dalam keluarga $(\mathrm{OR}=1,99 ; \mathrm{p}=0,03)$ menjadi faktor risiko, sedangkan frekuensi konsumsi makanan asin $(\mathrm{OR}=0,64 ; \mathrm{p}=0,10)$ menjadi faktor protektif. Setelah adjusted terhadap variabel lain, kemungkinan untuk hipertensi seorang wanita usia 40 tahun sebesar 42,9\% (IK95\%=33,7; $52,1 \%)$. Pencegahan untuk menurunkan prevalensi dan laju insidensi dapat dilakukan pada usia tersebut walaupun hanya ada dua faktor risiko yang dapat dimodifikasi.
\end{abstract}

Kata kunci: Faktor risiko, hipertensi, kemungkinan, usia, wanita

Received: 29 June 2020; Revised: 12 July 2020; Accepted: 28 July 2020; Published: 31 August 2020

Correspondence: Fajar Awalia Yulianto, dr., M.Epid. Department of Public Health, Faculty of Medicine, Universitas Islam Bandung. Jln. Tamansari No. 22, Bandung 40116, West Java, Indonesia. E-mail: awaliayulianto@gmail.com 


\section{Introduction}

Hypertension is currently the most significant prevalence of non-communicable disease (NCDs) in Indonesia, which was $34.1 \%$ according to the Basic Health Research (Riskesdas) 2018. ${ }^{1}$ In 2014, 15 million people of Indonesia was hypertension, but only $4 \%$ of them have controlled hypertension and sadly 50\% of them never been aware that they had hypertension due to its asymptomatic property until the illness started to make complications. ${ }^{2}$

From the 2016 annual report of the most frequent diseases in Pasirjambu Public Health Center (Puskesmas), hypertension was the most prominent NCD (Table 1). Pasirjambu is a village located in West Java province of Indonesia that was selected to assessed in community health assessment (CHA) due to its public health problem.

There are several risk factors for hypertension, including nonmodifiable risk factors; gender, age, family history, and modifiable risk factors; lack of physical activity, and other preventive measures. ${ }^{3}$ However, no previous research identified specific age in which hypertension occurs and which factors contribute the most notably in a rural area.

Hypertension is known as the primary causation for following organ damages such as stroke, heart attack, heart failure, kidney failure, etc. With the prevalence of hypertension soaring in the village, it is essential to figure out the specific risk factors that prevent further damage. This research aimed to assess the risk factors for hypertension in the community in Pasirjambu village.

\section{Methods}

This study's population was family members in Pasirjambu village Bandung regency of West Java province in Indonesia, divided into 30 clusters, and seven households have randomly taken on each cluster (rapid survey method). ${ }^{4}$ One individual was representing their respective family. There were 210 respondents in total data from each of the subjects collected during May 2017. The hypertension status assessed by trained medical students in a standardized method on each respondent's house. Blood pressure was measured twice by calibrated sphygmomanometer after five minutes of introduction, and the results were written in a form. ${ }^{5}$ The data were collected by nine enumerators using questions that originated from Indonesia Basic Health Research (Riskesdas). The questionnaire consisted of knowledge about hypertension risk factors from consumer behavior, risky foods, smoking habits, activity, family history with hypertension, body mass index, and stress. ${ }^{1}$ Enumerators read questions and choices of answers. Statistical analysis consisted of univariate, bivariate, and multivariate analyses. Difference analysis, such as the two groups $t$ test and chi-square, conducted in bivariate analysis. All variables correlation was analyzed by Pearson's correlation to prove no multiple colinearities before entered to a multivariate analysis by logistic regression. Studied risk factors were age, salty food (such as salty fish), processed food, home-produced noodles, kidney disease, and stress levels. All of them were categorized. ${ }^{6}$

Individual data of respondents not published in this article, their identity are safe. Published results contain the conclusion of the total data in the area that able to generalized to a larger population.

This study was approved by the Health Research Ethics Committee of the Faculty of Medicine, Universitas Islam Bandung, Indonesia No. 032/Ethics Committee.FK/VII/2017.

\section{Results}

Due to the incomparable group size, subjects who had kidney disease excluded, so the total respondents eligible in this study were 210 females. They are representing their household, particularly in family consumption patterns.

Table 1 Top Ten Diseases in Pasirjambu Puskesmas

\begin{tabular}{clc}
\hline No. & Disease & n \\
\hline 1 & Febrile observation & 4,241 \\
2 & Hypertension & 3,992 \\
3 & Acute respiratory tract infection & 3,131 \\
4 & Dental infection & 2,838 \\
5 & Fibromyalgia & 2,613 \\
6 & Dyspeptic syndrome & 2,512 \\
7 & Dermatitis & 1,939 \\
8 & Pharyngitis & 1,211 \\
9 & Diarrhea & 950 \\
10 & Common cold & 893 \\
\hline
\end{tabular}


Table 2 Number of Respondents with Hypertension based on Age in Pasirjambu Village in 2017

\begin{tabular}{|c|c|c|c|}
\hline Current & $\mathbf{n}$ & Age & $\mathbf{p}^{*}$ \\
\hline $\begin{array}{l}\text { Nypertension } \\
\text { Nonypertension }\end{array}$ & & Mean (SD) & \\
\hline Hypertension & 125 & $50.4(13.9)$ & \\
\hline Total & 210 & $52.9(14.6)$ & \\
\hline
\end{tabular}

Note: "t test, significant if $\mathrm{p}<0.05 ; \mathrm{SD}=$ standard deviation

There were 125 or $59.5 \%(95 \% \mathrm{CI}=52.9,66.2 \%)$ people with hypertension out of 210 respondents. The mean age in the hypertension group was 57.3 years old, significantly older than the opposite group $(\mathrm{p}<0.05)$.

The significant difference showed age was an essential explanatory variable to predict hypertension, thus from analysis on each group; we found that the youngest age who had hypertension was 27 years old. Table 2 illustrates the mean age of the hypertension group was 10.9 years older $(95 \% \mathrm{CI}=7.1,14.6 \%)$ than the mean age of the non-hypertension group.

Statistically, there was a significant proportionatedifferenceinsaltyfood consumption frequency in hypertension in Table 2, where percentages who had hypertension decreased. In contrast, the frequency of eating salty food was the opposite. Generally, respondents in this

Table 3 Risk Factors of Hypertension in Pasirjambu Village

\begin{tabular}{|c|c|c|c|c|}
\hline \multirow[b]{2}{*}{ Variables } & \multicolumn{2}{|c|}{ Hypertension } & \multirow[b]{2}{*}{ Total } & \multirow[b]{2}{*}{ p Value } \\
\hline & $\begin{array}{c}\text { No } \\
n=85(\%)\end{array}$ & $\begin{array}{c}\text { Yes } \\
n=125(\%)\end{array}$ & & \\
\hline \multicolumn{5}{|l|}{ Salty food } \\
\hline$<3 \times$ a month & $4(16.7)$ & $20(83.3)$ & 24 & \multirow{3}{*}{0.04} \\
\hline $1-6 \times$ a week & $56(43.1)$ & $74(56.9)$ & 130 & \\
\hline$>1 \times$ a day & $25(44.6)$ & $31(55.4)$ & 56 & \\
\hline \multicolumn{5}{|l|}{ Processed food } \\
\hline Never & $10(31.2)$ & $22(68.7)$ & 32 & \multirow{3}{*}{0.11} \\
\hline$<3 \times$ a month & $39(36.8)$ & $67(63.2)$ & 106 & \\
\hline $1 \times /$ week $->1 \times /$ day & $36(50)$ & $36(50)$ & 72 & \\
\hline \multicolumn{5}{|l|}{ Home made noodle } \\
\hline Never & $11(50)$ & $11(50)$ & 22 & \multirow{3}{*}{0.63} \\
\hline$<3 \times$ a month & $30(39)$ & $47(61)$ & 77 & \\
\hline $1 \times /$ week $->1 \times /$ day & $44(39.6)$ & $67(60.4)$ & 111 & \\
\hline \multicolumn{5}{|l|}{ Stress } \\
\hline Eustress & $57(46)$ & $67(54)$ & 124 & \multirow{2}{*}{0.05} \\
\hline Distress & $28(32.6)$ & $58(67.4)$ & 86 & \\
\hline \multicolumn{5}{|l|}{ Instant noodle } \\
\hline Never & $8(44.4)$ & $10(55.6)$ & 18 & \multirow{4}{*}{0.67} \\
\hline$<3 \times$ a month & $19(35.8)$ & $34(64.1)$ & 53 & \\
\hline $1-6 \times$ a week & $51(40.5)$ & $75(59.5)$ & 126 & \\
\hline$>1 \times$ a day & $7(53.8)$ & $6(46.1)$ & 13 & \\
\hline \multicolumn{5}{|l|}{ Monosodium glutamate } \\
\hline$<3 \times$ a month & $6(54.5)$ & $5(45.4)$ & 11 & \multirow{3}{*}{0.11} \\
\hline $1-6 \times$ a week & $15(28.8)$ & $37(71.2)$ & 52 & \\
\hline$>1 \times$ a day & $64(43.5)$ & $83(56.5)$ & 147 & \\
\hline \multicolumn{5}{|l|}{ Family history } \\
\hline No & $50(46.7)$ & $57(53.3)$ & 107 & \multirow[t]{2}{*}{0.06} \\
\hline Yes & $35(34)$ & $68(66)$ & 103 & \\
\hline \multicolumn{5}{|l|}{ Cigarette smoking } \\
\hline Never smoker & $67(41.1)$ & $96(58.9)$ & 163 & \multirow[t]{2}{*}{0.73} \\
\hline Ever smoker & $18(38.3)$ & $29(61.7)$ & 47 & \\
\hline
\end{tabular}

Note: "chi-square test, significant if $\mathrm{p}<0.05$ 
Table 4 Final Multivariate Analysisiof Hypertension

\begin{tabular}{lcccc}
\hline Hypertension & Coefficient & p (z) & p (Chi-squared) & Pseudo R-squared \\
\hline Age & 0.06 & 0.00 & & \\
Salty food & -0.45 & 0.10 & & \\
Stress & 0.55 & 0.09 & 0.00 & 0.14 \\
Family history & 0.69 & 0.03 & & \\
Honstant & -2.27 & 0.01 & & \\
\hline
\end{tabular}

study were all had contact with salty food but in different intensities.

The proportion of hypertension people was higher than the eustress group, which had positive hypertension familial history compared to the other group. Unfortunately, most of the respondents had routinely consumed processed food and monosodium glutamate (MSG). The proportion of hypertension subjects in processed food categories declined each time the frequency increased, with the number of processed food consumptions the largest in $<3$ times a month while that pattern did not appear in MSG's consumption.

Interesting parts found in other variables that consistently played as risk factors in hypertension, such as all kinds of noodles and smoking, which did not have a significant association with hypertension in this study. In order to have better reliability of the model, those variables excluded in multivariate analysis.

Stress and family history were factors that contribute to hypertension and $\mathrm{p}$ values near significant numbers (0.05). Although $\mathrm{p}$ values of processed food and MSG were more than

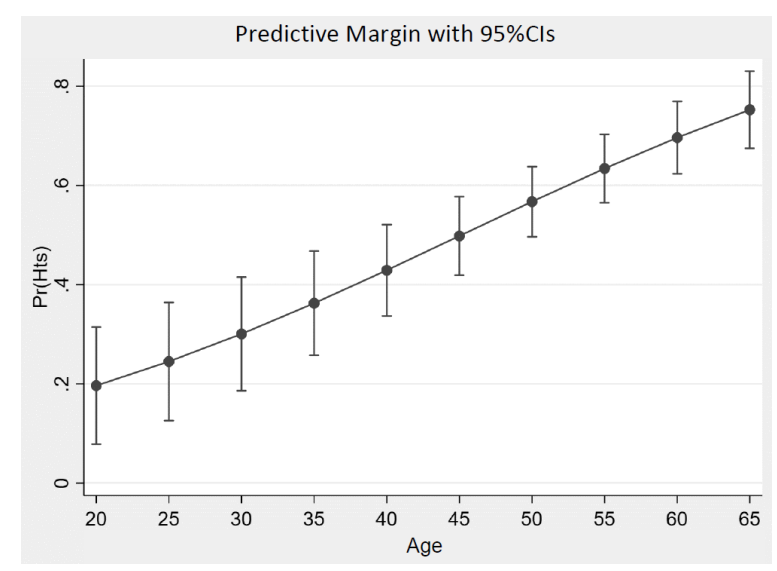

Figure Probability of Hypertension by Age Adjusted to Other Factors designated alpha, those variables included in the subsequent analysis (multivariate analysis) due to their $\mathrm{p}$ values of less than 0.30 . Multicollinearity between variables not found in correlation analysis, therefore those variables were included in logistic regression.

Age, salty food consumption, stress, and family history significantly were the risk factors for hypertension (p chi-squared 0.oo), where 14\% of hypertension variance accounted for them. The probability of getting hypertension generally $59.5 \%(95 \% \mathrm{CI}=53.5,65.5 \%)$ in that population, but stratified result by age describes other things (Figure). The ages classified into age categories ranging from five years to a minimum of 20 old (the youngest respondent's age).

The probability of getting hypertension was increasing overages linearly. The cut-off probability point was in 50\% (0.5) and visible in 40 years old group (mean probability $42.9 \%$, $95 \% \mathrm{CI}=33.7,52.1 \%)$. Over that age group, the probability of contracting hypertension was higher than not contracting hypertension.

\section{Discussion}

Although age has been consistently proven as a risk factor in hypertension in the world, the age's cut-off is varied, and many still unknown, especially in a big archipelago country like Indonesia. The Ministry of Health finding where the most significant proportion of hypertension in the young was found in 18 years old. ${ }^{1}$ Until today, the prevention of hypertension complication still be aimed at elderly (above 50 years old) in pos pembinaan terpadu (posbindu), a contrast to the previous finding. Therefore, the blood pressure monitoring must be conducted not only in posbindu but also in pos pelayanan terpadu (posyandu). Posbindu and posyandu are extended programs from pusat kesehatan masyarakat (puskesmas), primary health services in Indonesia, that reach communities. ${ }^{7}$ 
Certain posyandu have a blood pressure monitoring program that not limited only to the elderly. There are no specific rules for everyone who wants to check their blood pressure. Thus the screening would not be sufficient to reach all members of the population at risk. Although the programs in posyandu were for children, in particular, adults could come to certain posyandu for checking their health, including their blood pressure.

Other programs that always held in this national health insurance coverage, in every primary health services including the private sector, named program pengendalian penyakit kronis (Prolanis), which is not limited to certain ages because aimed to every chronic disease including hypertension. ${ }^{8}$ This program was launched by national health insurance of Indonesia to control the complication of hypertension, as one of the chronic diseases, but not intended to detect early high-risk groups.

The prevalence of hypertension is high in Indonesia, especially West Java, one of the three prominent provinces of hypertension. This province has a salty cooking habit in almost every kind of food, from sambal until sayur lodeh. ${ }^{1}$ However, the result for the consumption of salty food illustrates interesting results where the frequency of hypertension people was getting lesser on every increasing frequency of consumption. The ratio between three groups of consumption was 1:5:2, the biologic gradient between exposure and outcome not yet established. However, the result describes consistency that the hypertension proportion is more significant in every group coherent with the theory that salt $(\mathrm{NaCl})$ as a cause for hypertension.

Salt is the most common food preservatives used in processed food. ${ }^{9}$ Sodium as a molecule of salt. It retains fluid as an antidiuretic. Consequently, large amounts of water enter the blood vessel and create a rise in blood pressure. Thus, hypertension occurred. ${ }^{10}$

Other than salt, MSG also has sodium property and becoming a common food additive in Indonesia. Their "umami" property adds the depth of taste besides four regular tastes (sweet, sour, bitter, and spicy). ${ }^{11}$ They are known as seasoning ingredients in instant noodles, a favorite food that famous by their low price, their cooking simplicity, and their delicious taste. Only with 2,000 IDR (0.14 USD) individual will have a serving packed with $490 \mathrm{kcal}$ energy with $53 \%$ of daily sodium needs fulfilling. By their advantages, no wonder the percentage of people who eat instant noodles is the most significant one to six times a week. Homemade noodle was also studied because the researchers want to know the frequency of unstandardized salt and MSG in that kind of noodle. It was including dried-noodle that seasoned with specific personalized dosage. However, there was no significant association between the frequency of eating instant noodles or homemade noodles with hypertension.

On the contrary, this study showed no significant association between cigarette smoking and hypertension. With subjects were all women, there might be modifying the effect between sex and smoking habit. Further study of adjusted risk factors must be included. From the previous study, some of the results show lower blood pressure in the group who smoke compared to never and ex-smoker, particularly in men. ${ }^{12,13}$ Against the coherent theory of endothelial damage by smoking, ${ }^{14-16}$ this finding must be studied further with extended regression to see interactions in sex stratum or unobserved confounders.

Blood pressure in the elderly will tend to be high so that older people are at greater risk of developing hypertension. Increasing age results in increased blood pressure because arterial walls thickened as a result of the accumulation of collagen in the muscle layer, thus the blood vessels will become gradually narrower and stiffer. Eventually, an older person is at risk of getting hypertension due to the bloodstream that passing the narrow and stiff vessels. ${ }^{17,18}$

As a developed country, Indonesia has to advance in many aspects, including food consumption. Citizens of Indonesia barely have a problem to access every kind of food, including salt-excess delicacies. Therefore, the exposure of salt in Indonesia in general. Salt, as the taste intensifier, is a common ingredient in nearly all kinds of food in Indonesia, particularly in West Java province, where the study conducted. There is a custom in Sundanese, the tribe that dominantly resides in West Java; it was not tasty if it was not salty.

Eating with a high sodium content can affect blood pressure in the body, causing hypertension. ${ }^{10}$ Effect of sodium intake on hypertension through increased blood volume, cardiac output, and blood pressure. An increase follows this situation in excess salt's excretion, 
so that returns to a normal hemodynamic state. This mechanism disrupted in hypertension with unknown causes, and other factors affect it. Hypertension rarely found with minimal salt intake. Recommended salt intake for an adult is less than 2,000 mg of sodium or $5 \mathrm{~g}$ of salt. ${ }^{19}$

Seasoning and ingredients in noodles use monosodium glutamate (MSG) or vetsin. Vetsin is an organic salt between sodium and glutamate. ${ }^{11}$ Besides, the weakness of consuming noodles is the high sodium content. Sodium contained in noodles comes from salt $(\mathrm{NaCl})$ and the ingredients of the developer. The commonly used development material is sodium tripolyphosphate, reaching $1 \%$ of the total weight of noodles per serving. Sodium harms hypertensive patients. ${ }^{20}$

High blood pressure caused by various factors, one of which is stress. Stress is a nonspecific response from the body to any pressure or demand that may arise from pleasant and unpleasant conditions. Stress can lead to hypertension through the sympathetic nervous system's activation, which results in increased blood pressure intermittently. ${ }^{21}$ When a person experiences stress, adrenaline will be released and then increase blood pressure through an arterial contraction (vasoconstriction) and increased heart rate. If stress continues, blood pressure will remain high so that the person will experience hypertension.

One of the interesting findings in this study is how the frequency of salty food consumption affecting hypertension. There was a negative correlation on the proportion of hypertensive people in the increasing frequency of consumption, which is a contradiction to theory that more exposure accompanied by more outcome (positive dose-response relationship in Hill's criteria for causal relationship)..$^{22}$ There is a theory that can support the result of this research about how salt sensitivity of blood pressure (SSBP) controls blood pressure variability. For the salt-sensitive (SS) group, the positive doseresponse relationship will occur, but this result will not seem in the salt-resistant (SR) group. ${ }^{23}$ However, further study must be conducted in the Pasirjambu area to conclude the SSBP of the population.

\section{Conclusion}

The probability of hypertension is increasing following ages, with risk factors such as stress, frequency of salty food consumption, and family history of hypertension.

\section{Conflict of Interest}

The author declares that there is no conflict of interest in this study.

\section{Acknowledgments}

The author would like to express his gratitude to the Head of Pasirjambu village.

\section{References}

1. Badan Penelitian dan Pengembangan Kesehatan, Kementerian Kesehatan Republik Indonesia. Hasil utama Riskesdas 2018 [Internet]. Jakarta: Kementerian Kesehatan Republik Indonesia; 2019 [cited 2020 July 8]. Available from: https://www.litbang. kemkes.go.id/hasil-utama-riskesdas-2018.

2. Pusat Data dan Informasi, Kementerian Kesehatan Republik Indonesia. Hipertensi [Internet]. Jakarta: Kementerian Kesehatan Republik Indonesia; 2015 [cited 2020 July 8]. Available from: https://pusdatin.kemkes. go.id/resources/download/pusdatin/ infodatin/infodatin-hipertensi.pdf.

3. Ramdhani R, Respati T, Irasanti SN. Karakteristik dan gaya hidup pasien hipertensidi Rumah Sakit Al-Islam Bandung. GMHC. 2013;1(2):63-8.

4. Ashton RA, Kefyalew T, Tesfaye G, Pullan RL, Yadeta D, Reithinger R, et al. Schoolbased surveys of malaria in Oromia Regional State, Ethiopia: a rapid survey method for malaria in low transmission settings. Malar J. 2011;10:25.

5. Pickering TG, Hall JE, Appel LJ, Falkner BE, Graves J, Hill MN, et al. Recommendations for blood pressure measurement in humans and experimental animals: part 1: blood pressure measurement in humans: a statement for professionals from the Subcommittee of Professional and Public Education of the American Heart Association Council on High Blood Pressure Research. Hypertension. 2005;45(1):142-61.

6. Peat J, Barton B. Medical statistics: a guide to data analysis and critical appraisal. New York: John Wiley \& Sons; 2008. 
7. Rahmayanti E, Hargono A. Implementasi surveilans faktor risiko penyakit tidak menular berbasis posbindu berdasarkan atribut surveilans (studi di Kota Surabaya). JBE. 2017;5(3):276-85.

8. Lumempouw DO, Wungouw HIS, Polii H. Pengaruh senam prolanis terhadap penyandang hipertensi. eBiomedik. 2016; 4(1):11697.

9. Gutiérrez OM. Sodium and phosphorus-based food additives: persistent but surmountable hurdles in the management of nutrition in chronic kidney disease. Adv Chronic Kidney Dis. 2013;20(2):150-6.

10. Grillo A, Salvi L, Coruzzi P, Salvi P, Parati G. Sodium Intake and Hypertension. Nutrients. 2019;11(9):1970.

11. Melis M, Barbarossa IT. Taste perception of sweet, sour, salty, bitter, and umami and changes due to l-arginine supplementation, as a function of genetic ability to taste 6-n-propylthiouracil. Nutrients. 2017;9(6): 541.

12. Okubo Y, Miyamoto T, Suwazono Y, Kobayashi E, Nogawa K. An association between smoking habits and blood pressure in normotensive Japanese men. J Hum Hypertens. 2002 Feb;16(2):91-6.

13. Okubo Y, Suwazono Y, Kobayashi E, Nogawa K. An association between smoking habits and blood pressure in normotensive Japanese men: a 5-year follow-up study. Drug Alcohol Depend. 2004;73(2):167-74.

14. Virdis A, Giannarelli C, Neves MF, Taddei S, Ghiadoni L. Cigarette smoking and hypertension. Curr Pharm Des. 2010;16(23): 2518-25.

15. Gloria-Bottini F, Banci M, Neri A, Magrini A, Bottini E. Smoking and hypertension: effect of adenosine deaminase polymorphism. Clin Exp Hypertens. 2019;41(6):548-51.

16. Sohn K. Relationship of smoking to hypertension in a developing country. Glob Heart. 2018;13(4):285-92.

17. McEniery CM, Wilkinson IB, Avolio AP. Age, hypertension and arterial function. Clin Exp Pharmacol Physiol. 2007 Jul;34(7):665-71.

18. Robles NR, Macias JF. Hypertension in the elderly. Cardiovasc Hematol Agents Med Chem. 2015;12(3):136-45.

19. World Health Organization. WHO issues new guidance on dietary salt and potassium [Internet]. Geneva, Switzerland: World Health Organization; 2013 [cited 2020 July 8]. Available from: https://www.who. int/mediacentre/news/notes/2013/salt_ potassium_20130131/en.

20. Khomsan A. Pangan dan gizi untuk kesehatan. Jakarta: PT Raja Grafindo Persada; 2003.

21. Spruill TM. Chronic psychosocial stress and hypertension. Curr Hypertens Rep. 2010; 12(1):10-6.

22. Fedak KM, Bernal A, Capshaw ZA, Gross S. Applying the Bradford Hill criteria in the $21^{\text {st }}$ century: how data integration has changed causal inference in molecular epidemiology. Emerg Themes Epidemiol. 2015;12:14.

23. Elijovich F, Weinberger $\mathrm{MH}$, Anderson CA, Appel LJ, Bursztyn M, Cook NR, et al.; American Heart Association Professional and Public Education Committee of the Council on Hypertension; Council on Functional Genomics and Translational Biology; Stroke Council. Salt sensitivity of blood pressure: a scientific statement from the American Heart Association. Hypertension. 2016;68(3):e746. 